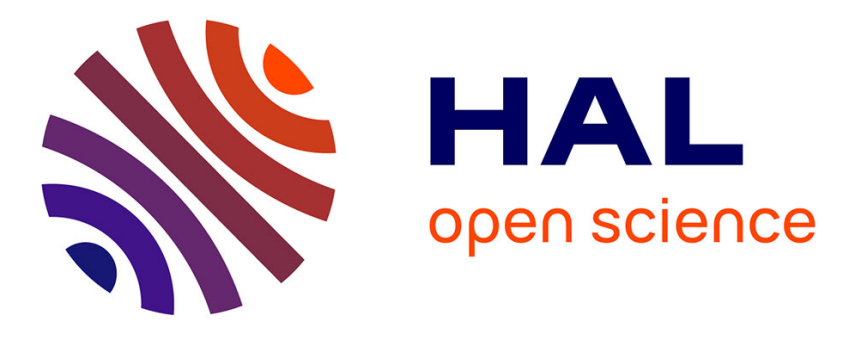

\title{
Priority pollutants in urban stormwater: Part 2 - Case of combined sewers
}

Johnny Gasperi, Sally Zgheib, Mathieu Cladière, Vincent Rocher, Régis Moilleron, Ghassan Chebbo

\section{- To cite this version:}

Johnny Gasperi, Sally Zgheib, Mathieu Cladière, Vincent Rocher, Régis Moilleron, et al.. Priority pollutants in urban stormwater: Part 2 - Case of combined sewers. Water Research, 2012, 46 (20), pp.6693-6703. 10.1016/j.watres.2011.09.041 . hal-00657039

\section{HAL Id: hal-00657039 \\ https://hal-enpc.archives-ouvertes.fr/hal-00657039}

Submitted on 5 Jan 2012

HAL is a multi-disciplinary open access archive for the deposit and dissemination of scientific research documents, whether they are published or not. The documents may come from teaching and research institutions in France or abroad, or from public or private research centers.
L'archive ouverte pluridisciplinaire HAL, est destinée au dépôt et à la diffusion de documents scientifiques de niveau recherche, publiés ou non, émanant des établissements d'enseignement et de recherche français ou étrangers, des laboratoires publics ou privés. 


\title{
PRIORITY POLLUTANTS IN URBAN STORMWATER: PART 2 - CASE OF COMBINED SEWERS
}

\author{
Johnny Gasperi $^{{ }^{*}}$, Sally Zgheib ${ }^{2,3}$, Mathieu Cladière ${ }^{1}$, Vincent Rocher ${ }^{4}$, \\ Régis Moilleron ${ }^{1}$, Ghassan Chebbo ${ }^{2}$
}

1. Université Paris-Est, LEESU, UMR MA 102 - AgroParisTech, 61 avenue du Général de Gaulle, 94010 Créteil Cedex, France.

2. Université Paris-Est, LEESU, UMR MA 102 - AgroParisTech, 77455 Marne-la-Vallée 2, France.

3. Lebanese Center for Water Management and Conservation / United Nations Development Programme (UNDP), Ministry of Energy and Water, Corniche du fleuve, Beirut (Lebanon).

4. SIAAP, Direction du Développement et de la Prospective, 82 avenue Kléber, 92700 Colombes, France.

\begin{abstract}
This study has evaluated the quality of combined sewer overflows (CSO) in an urban watershed, such as Paris, by providing accurate data on the occurrence of priority pollutants (PPs) and additional substances, as well as on the significance of their concentrations in comparison with wastewater and stormwater. Of the 88 substances monitored, 49 PPs were detected, with most of these also being frequently encountered in wastewater and stormwater, thus confirming their ubiquity in urban settings. For the majority of organic substances, concentrations range between 0.01 and $1 \mu \mathrm{g} .1^{-1}$, while metals tend to display concentrations above $10 \mu \mathrm{g} \cdot \mathrm{l}^{-1}$. Despite this ubiquity, CSO, wastewater and stormwater feature a number of differences in both their concentration ranges and pollutant patterns. For most hydrophobic organic pollutants and some particulate-bound metals, CSOs exhibit higher concentrations than those found in stormwater and wastewater, due to the contribution of in-sewer deposit erosion. For pesticides and $\mathrm{Zn}$, CSOs have shown concentrations close to those of stormwater, suggesting runoff as the major contributor, while wastewater appears to be the main source of volatile organic compounds. Surprisingly, similar concentration ranges have been found for DEHP and tributyltin compounds in CSOs, wastewater and stormwater. The last section of this article identifies substances for which CSO discharges might constitute a major risk of exceeding Environmental Quality Standards in receiving waters and moreover indicates a significant risk for PAHs, tributyltin compounds and chloroalkanes. The data generated during this survey can subsequently be used to identify PPs of potential significance that merit further investigation.
\end{abstract}

\section{Keywords}

Combined sewer overflows, priority pollutants, urban area, stormwater, Water Framework

Directive.

\footnotetext{
*Corresponding author: Fax: +33 (0)1 451716 27, e-mail: gasperi@u-pec.fr
} 


\section{1. Introduction}

The European Community's strategy for combating surface water pollution by means of a control policy was set forth in the European Water Framework Directive 2000/60/EC (WFD). Decision no. 2455/2001/EC, adopted by the European Parliament and Council on November 20, 2001, established the list of priority substances in the field of water policy and amended Directive 2000/60/EC. This decision provided the first list of 33 substances or groups of substances to be identified as action priorities at the Community level. Among these priority pollutants (PPs), some have been identified as "priority hazardous substances", whose emissions, discharges and losses are scheduled to be phased out or completely removed. More recently, on July 17, 2006, the Commission adopted a Directive intended to set mandatory environmental quality standards on priority substances, requiring Member States to come into compliance by 2015 in order to ensure a "satisfactory chemical status for surface water".

In pursuit of these WFD objectives through identifying possible pollutant reduction measures, an inventory of sources in the urban environment has definitely proven necessary. Since priority pollutants can enter aquatic ecosystems via effluents from wastewater treatment plants and industries, as well as via combined sewer overflows (CSOs) and stormwater, accurate knowledge of the PPs discharged by such sources is required. Even though a number of studies or National Action Plans have been undertaken to identify the occurrence and significance of specific PPs in wastewater (Rule et al., 2006a, b; Rowsell et al., 2010; Eriksson et al., 2010), in wastewater treatment plant effluent (Ruel et al., 2010) and in the aquatic system (Gasperi et al., 2009), no comprehensive broad overview of the PP contamination of stormwater in both separate and combined sewers is available. The continued existence of uncontrolled or poorly-controlled discharges from stormwater and CSOs could however constitute a major reason for the long-term persistence of low-quality water (Clark et al., 2006). Moreover, the magnitude of stormwater pollutant loads, their 
1 subsequent acute impact on receiving waters and their reliable and sensitive modelling have all remained key issues since 1990 (Chebbo and Saget, 1995; Deletic, 1998; Suarez and Puertas, 2005; Lau et al., 2009; Dotto et al., 2010). Although Eriksson et al. (2007) proposed a list of substances based on a theoretical assessment of stormwater substances (CHIAT: Chemical Hazard Identification and Assessment Tool), this list has not yet been experimentally screened on stormwater samples. To date, only limited information is available on a number of historical substances such as metals, polycyclic aromatic compounds (PAHs) and polychlorinated biphenyls (PCBs) (Iannuzzi et al., 1997; Gromaire et al., 2001; Davis et al., 2001; Rossi et al., 2004).

Due to this lack of information available on PP levels in urban stormwater in both separate and combined sewers, the OPUR research programme (Observatory of Urban Pollutants, 2006-2012) has sought to investigate stormwater quality in urban watersheds. The general objective herein has been to provide data on both the occurrence and concentration of PPs along with a few additional substances in stormwater and CSOs. A methodology based on the EU's list of priority substances and the CHIAT approach was therefore developed by Zgheib et al. (2008) in conjunction with a list of 88 pollutants (containing 80 organic substances and 8 metals) and ultimately adopted in order to monitor stormwater quality. In considering that the analyses carried out on unfiltered samples yield poor-quality data with respect to the representativeness of sample contamination in addition to offering only partial information on the chemical fate, the applicable methodology requires analysing both the dissolved and particulate fractions. The first step of the OPUR programme was dedicated to stormwater quality in connection with the urbanisation gradient (from residential to more densely urbanised areas, Figure 1). This work is partially described in Zgheib et al. (2011a) and then more extensively discussed in Zgheib et al. (2011b, same issue). In accordance with the same methodology and approach, the present study, as the second part in a two-article 
1 series, focuses on CSO quality. The largest CSO outfall in the Paris metropolitan area was

equipped and a total of $4 \mathrm{CSO}$ discharges were considered. Since CSOs make up a mixture of untreated wastewater and stormwater, the wastewater quality was also investigated according to the same methodology (i.e. through monitoring of the 88 pollutants identified). This study therefore is the first relevant assessment to provide new and accurate knowledge on the occurrence and concentrations of a wide array of pollutants in CSOs and on their significance in comparison with concentrations found in wastewater and stormwater. The final objective of this paper is to determine the potential impact of CSO discharges in receiving waters, as regards Environmental Quality Standards (EQS).

\section{Materials and methods}

\subsection{Site description and rain event characteristics}

Paris proper (intra-muros) is drained by a combined sewer system covering a land area of $105 \mathrm{~km}^{2}$. This area is densely populated (2.15 million inhabitants, i.e., approximately 20,500 inhabitants $/ \mathrm{km}^{2}$ ) and features many small shops, offices and very little industrial activity. In this study, the largest CSO outfall, located in Paris' north-western district, has been considered ("Clichy" outfall, Figure 1). Over the 2009-2010 period, some 52 discharges occurred annually, responsible for discharging between 25,000 and $1,000,000 \mathrm{~m}^{3}$ into the Seine River. This outfall is supervised by the Paris public sanitation service (SIAAP).

In order to collect CSO samples, flow was continuously monitored using an automatic flowmeter that combined water level and velocity sensors; moreover, water samples were collected by two automatic vacuometric samplers equipped with glass and plastic bottles for organic and inorganic sampling, respectively. Teflon pipes were also used. Samples were removed at a fixed time interval (about $5 \mathrm{~min}$ ), and 6 sub-samples per bottle were collected. The bottles were then picked up in order to produce a flow-weighted composite sample 
1 representative of the entire rain event as determined by flow rate measurements. A total of 4

2 CSO discharges were thus collected. Table 1 summarises the main characteristics of the rain

events and discharges (precipitation height, volume discharged, conductivity, etc.). Two exceptional discharges, corresponding to summer storms, were collected on July $12^{\text {th }}$ and $14^{\text {th }}, 2010$ (C1 and C2 event designation), with volumes of roughly 600,000 and $1,000,000$ $\mathrm{m}^{3}$, respectively. Moderate discharges (September $8^{\text {th }}$ and $\left.24^{\text {th }}, 2010\right)$ were also collected (C3 and C4 event designation). This type of discharge has been the most frequently observed at the Clichy outfall over the last 2 years, during which time a discharge range from 40,000 to $300,000 \mathrm{~m}^{3}$ has encompassed about $80 \%$ of all discharges. At the same site, wastewater was also collected and analysed. According to the conductivity of raw sewage (between 1,050$1,170 \mu \mathrm{S} . \mathrm{cm}^{-1}$ measured on the site during dry periods) and values provided by Kafi et al. (2008) for runoff $\left(80-150 \mu S . \mathrm{cm}^{-1}\right)$, the runoff and wastewater proportions can be calculated with a simple linear regression using the conductivity of the flow-weighted composite sample since conductivity is conservative. To consider uncertainties in the method calculation, the minimal and maximal runoff proportions were calculated (hypothesis min: 1,050 and $150 \mu \mathrm{S} . \mathrm{cm}^{-1}$ for runoff and wastewater, hypothesis max: 1,170 and $80 \mu \mathrm{S} . \mathrm{cm}^{-1}$, respectively).

For the studied discharges, the proportion of runoff remains especially high (at least $69 \%-75 \%$ of runoff). The discharges on July $14^{\text {th }}(\mathrm{C} 2)$ exhibited the highest runoff proportion, while the September $8^{\text {th }}(\mathrm{C} 3)$ value was noteworthy for its slightly lower runoff proportion (Table 1). Other discharges (C1 and $\mathrm{C} 4)$ revealed runoff proportions of between $75 \%$ and $89 \%$. Similar estimations based on nitrogen concentration provided comparable results. 


\subsection{Experimental procedure}

\section{Routine wastewater parameters}

For each sample, routine wastewater parameters, such as total solids (TS), chemical and biochemical oxygen demands $\left(\mathrm{COD}\right.$ and $\left.\mathrm{BOD}_{5}\right)$, ammonium $\left(\mathrm{NH}_{4}{ }^{+}\right)$, total Kjeldahl nitrogen (TKN), total phosphorous (Ptot) and orthophosphates $\left(\mathrm{PO}_{4}{ }^{3-}\right)$, were analysed. As reported in Supporting Table 1, these parameters were measured in accordance with French standards.

\section{Priority substances}

As described by Zgheib et al. (2011b, same issue), a total of 88 substances were monitored for each sample (Table 2). Except for metals and volatile organic compounds (VOCs) including halogenated volatile organic compounds and BTEX (benzene* (in this article, priority hazardous substances are marked with *), toluene, ethylbenzene and xylenes) which were analysed on the total fraction, both dissolved and particulate fractions were assessed for each individual compound. Analysis was performed by the IPL-Brittany Laboratory, certified by the French Ministry of Ecology, Sustainable Development, Transport and Housing (via the COFRAC accreditation committee).

\section{Results and discussion}

\subsection{Wastewater quality parameters in combined sewer overflows}

Routine wastewater quality parameters for the collected discharges as well as for a large number of rain events (SIAAP CSO database, $n=52$ ) are given in Table 3. Data for wastewater (on the same site) and runoff (Kafi et al., 2008) are also reported. In spite of a high runoff proportion, the CSO reveals an organic strength (COD concentrations greater than $140 \mathrm{mg} \cdot \mathrm{l}^{-1}, \mathrm{BOD}_{5}$ above $40 \mathrm{mg} \cdot \mathrm{l}^{-1}$ ), albeit with less household wastewater than is typical (Tchobanoglous et al., 2003). While C1 and C4 discharges were quite similar in their 
1 concentrations of carbonaceous pollution, differences were still observed between $\mathrm{C} 2$ (the lowest concentration) and C4 (the highest). These differences may be partially tied to: i) the relative proportion of wastewater that gets mixed with runoff, and ii) the previous dry period prior to these rain events. A rougher comparison of CSO and wastewater concentrations allows differentiating two groups of parameters. The first group, which includes $\mathrm{BOD}_{5}, \mathrm{TKN}$ and $\mathrm{NH}_{4}^{+}$, exhibits higher wastewater concentrations than the group observed during the storm period, thus underscoring the fact that wastewater constitutes the major source for these pollutants. In the literature, it is well documented that most of these elements originate mainly from human sources (especially via urine and faeces) and from various activities such as washing and cooking (Wilkie et al., 1996; Tchobanoglous et al., 2003). More recently, Gasperi et al. (2010) confirmed that wastewater is the major source of organic and nitrogenous pollution in CSOs. The second group comprised COD, TS and Ptot, with these parameters presenting comparable wastewater and CSO concentrations. While urban runoff contains rather low COD, TS and Ptot concentrations, wastewater dilution by runoff should induce even lower CSO concentrations. This trend however was not observed, owing to the erosion of in-sewer deposits accumulated during dry weather flow periods in sewer trunks (Gromaire et al., 2001). At the scale of Paris' combined sewer, Gasperi et al. (2010) indicated that from $47 \%$ to $69 \%$ for TS and from $34 \%$ to $61 \%$ for COD are tied to the erosion of insewer deposits; on the other hand, runoff only plays a minor role.

\subsection{Priority pollutants in combined sewer overflows}

Priority pollutants and detection frequency

Depending on the rain event under consideration $(\mathrm{C} 1, \mathrm{C} 2, \mathrm{C} 3$ and $\mathrm{C} 4)$, between 34 and 44 PPs were detected. While the number of detected PPs ranges between 34 and 38 for $\mathrm{C} 1$, $\mathrm{C} 2$ and $\mathrm{C} 3, \mathrm{C} 4$ with the highest wastewater proportion exhibited the greatest number of detected PPs $(\mathrm{n}=44)$. On the whole, 39 PPs were never detected in CSOs. In comparison, 33 
1 and 25 PPs were never quantified in stormwater (Zgheib et al., 2011, same issue) and wastewater (Zgheib et al., 2010), respectively. Out of these 39 never detected PPs and by comparing all matrices (CSO, wastewater and runoff), 30 substances were either never detected or only detected with a frequency of less than $15 \%$ (Table 4). The full list of undetected molecules, as well as their detection and quantification limits, is provided in Supporting Table 2. The non-quantification of most molecules may be explained by the levels of these chemicals lying below the available analytical limits of detection (as is typically the case for low-level metals such as Cd* or Pt, PCB 194, or octa-BDE). For other substances, their non-quantification is indicative of being phased out in France and removed from the market (which is the case for several banned pesticides, hexachlorobenzene* or carbon tetrachloride). Of the 88 priority substances monitored in both the particulate and dissolved phases, 49 different PPs including 19 priority hazardous substances* (PHS*) were detected (Table 4).

Priority pollutant concentrations and comparison with levels found in wastewater and stormwater

To better visualise the PP contamination of CSOs, the total even mean concentrations (expressed in $\mu \mathrm{g} \cdot \mathrm{l}^{-1}$ ) for the discharges considered have been reported in Figure 4. The concentrations of 58 PPs (i.e. 88 PPs monitored minus 30 PPs never detected) are illustrated. Additional information on dissolved and particulate concentrations is provided in Supporting Table 3. In comparing the quality of CSO with that of other matrices, the concentrations found for stormwater (n=15, Zgheib et al., 2011 - same issue) and for wastewater have also been given in Figure 4. For both matrices, the median concentrations (d50) as well as the first and last deciles (d10 and d90) are listed. For wastewater, since no significant differences in wastewater contamination were observed between Clichy $(\mathrm{n}=7)$ and other experimental sites $(n=4)$, all data on wastewater quality were compiled $(n=11)$. For each matrix and compound, 
1 the frequency of detection (\%) is also indicated. Moreover, Figure 4 illustrates the ratios between CSO concentrations and the median wastewater or runoff concentrations.

Metals

High concentrations of $\mathrm{Zn}\left(658-1,137 \mu \mathrm{g} .1^{-1}\right), \mathrm{Cu}\left(86-134 \mu \mathrm{g} .1^{-1}\right)$ and $\mathrm{Pb}^{*}\left(46-175 \mu \mathrm{g} .1^{-}\right.$

$\left.{ }^{1}\right)$ were observed in CSOs. Cr was also noticeable yet at lower concentrations $\left(12-20 \mu \mathrm{g} .1^{-1}\right)$, in accordance with the low levels reported in domestic wastewater (Comber and Gunn, 1996). From an overall perspective, the metal concentrations found were close to those reported by Gromaire et al. (2002) in wet weather flows at the scale of the Marais catchment (centre of Paris, $4^{\text {th }}$ arrondissement): $1,024-3,343 \mu \mathrm{g} .1^{-1}$ for $\mathrm{Zn}, 132-377 \mu \mathrm{g} .1^{-1}$ for $\mathrm{Pb}^{*}$, and $58-208 \mu \mathrm{g} .1^{-1}$ for $\mathrm{Cu}$. These results resembled those found by Kafi et al. (2008) at the largest Paris city scale (760-1,832 $\mu \mathrm{g} . \mathrm{l}^{-1}$ for $\mathrm{Zn}, 55-289 \mu \mathrm{g} . \mathrm{l}^{-1}$ for $\mathrm{Pb}^{*}$ and $66-231 \mu \mathrm{g} . \mathrm{l}^{-1}$ for $\mathrm{Cu}$ ).

As illustrated in Figures 1 and 2, CSO exhibits higher $\mathrm{Cu}$ and $\mathrm{Pb} *$ concentrations and a much higher $\mathrm{Zn}$ concentration than those of wastewater. As initially reported by Gromaire et al. (2001), and depending on the metal under consideration, these differences may be explained by: i) the high metal concentrations found in runoff, or ii) in-sewer deposit erosion. As regards $\mathrm{Cu}$ and according to the authors, runoff and wastewater are only minor contributors (less than 30\%), while exchanges with in-sewer stocks remain a considerable source (30\%-70\%). For $\mathrm{Zn}$ and $\mathrm{Pb}^{*}$, runoff serves as the main source of CSO pollution at the scale of the Paris sewer network. This strong contribution from runoff is highly correlated with the heavy metal contamination of roof runoff. Gromaire et al. (2002) demonstrated that such heavy metal contamination is mainly correlated with Paris' roofs since most of them feature metal roof coverings and fittings.

As for $\mathrm{Zn}$ and $\mathrm{Pb}^{*}$, CSOs also exhibit higher concentrations than those measured in stormwater by Zgheib et al. (2011b, same issue). The difference observed is mainly explained by the change in land use between suburban catchments and the Paris metropolitan area. 
1 While the suburban catchments considered by Zgheib et al. (2011b, same issue) to

characterise stormwater are residential (most buildings equipped with tile roofs), the majority of roofs within the Paris city limits have been fitted with metal materials, such as lead fittings and zinc sheets, thus leading to high metal concentrations.

\section{Polycyclic Aromatic Hydrocarbons (PAHs)}

In this study, all 16 US-EPA PAHs were monitored: naphthalene* $(\mathrm{N})$, acenaphthalene (Acen), acenaphthylene (Acyl), fluorene (F), phenanthrene (P), anthracene* (A*), fluoranthene* (Fluo*), pyrene (Pyr), benzo[a]anthracene (B(a)A), chrysene (Chry), benzo $[a]$ pyrene* $\left(\mathrm{B}(\mathrm{a}) \mathrm{P}^{*}\right)$, benzo $[b]$ fluoranthene* $\left(\mathrm{B}(\mathrm{b}) \mathrm{F}^{*}\right)$, benzo $[k]$ fluoranthene* $\left(\mathrm{B}(\mathrm{k}) \mathrm{F}^{*}\right)$, dibenz[ah]anthracene $(\mathrm{D}(\mathrm{ah}) \mathrm{A})$, benzo[ghi]perylene* $(\mathrm{B}($ ghi) $\mathrm{P} *)$, and indeno $[c d]$ pyrene * (IP*). The CSO concentrations of $\Sigma 16$ PAHs ranged from 0.98 to $2.58 \mu \mathrm{g} .1^{-1}$. Concentrations found in CSOs were typically within the same range as those reported by Kafi et al. (2008) (1.04-4.81 $\mu \mathrm{g} . \mathrm{l}^{-1}$ for $\Sigma 16$ PAHs, with the median equalling $2.12 \mu \mathrm{g} . \mathrm{l}^{-1}$ ). No special relationship between PAH concentrations and the proportion of runoff was observed. PAHs were correlated with TS since they are preferentially associated with particulate matter (> $85 \%$ for $\Sigma 16$ PAHs). PAHs with light molecular weights (LMW, 2 or 3 benzene rings) were predominant in dissolved phase, while PAHs with high molecular weights (HMW, 4 to 6 benzene rings) were predominant in particulate phase. For $\Sigma 16$ PAHs, HMW contributes to more than $75 \%$ of total PAHs. As suggested by this predominance and the high contributions of fluoranthene* and pyrene (approx. 15\% each), the PAH distribution confirms the pyrolytic origins of this contamination (Soclo et al., 2000). This contamination can certainly be correlated with the high density of combustion sources inside Paris city limits. The Paris metropolitan area indeed generates heavy road traffic; consequently, both diesel- and gasoline-powered vehicles are responsible for emitting great quantities of PAH into the environment. 
In sum, CSO concentrations appear to be higher than those measured in wastewater and stormwater at suburban catchment outlets (spanning the range from residential to densely-populated urbanised areas). Stormwater concentrations actually varied between 0.77 and $6.14 \mu \mathrm{g} . \mathrm{l}^{-1}$ (with the median at $1.36 \mu \mathrm{g} \cdot \mathrm{l}^{-1}$ ), while the concentrations found in wastewater occupied the $0.20-1.22 \mu \mathrm{g} . \mathrm{l}^{-1}$ range (median: $0.47 \mu \mathrm{g} . \mathrm{l}^{-1}$ ). As previously explained for $\mathrm{Cu}$ and organic matter, the erosion of in-sewer deposits can explain the differences observed. According to Gasperi et al. (2010), who established the mass balance of PAH loads during wet weather flows, the wastewater and runoff contributions do not exceed $30 \%$, while insewer processes constitute a major source of PAHs (between $40 \%$ and $70 \%$ ).

\section{Polychlorinated biphenyls (PCBs)}

Despite being banned in France since 1987, six congeners (PCB 28, 101, 118, 138, 153 and 180) were commonly detected in CSOs with total concentrations ranging from 12 to 26 ng. $1^{-1}$ (Fig. 1). These concentrations found in CSOs were lower than those reported by Rossi et al. (2004) in stormwater (0.11-403 ng. . $\left.^{-1}\right)$. The authors however have reported similar PCB distributions dominated by heavy congeners (PCB 138, 153 and 180), thus reflecting typically diffuse inputs (Chevreuil et al., 1996).

As for PAHs, rainy periods enhance PCB wastewater concentrations (Figs. 1 and 2). During dry periods, low PCB levels have been measured in wastewater (2.0-12.0 ng. $\mathrm{l}^{-1}$, with the median at $4.2 \mathrm{ng} . \mathrm{l}^{-1}$ ), which shows good agreement with the values reported by Vogelsang et al. (2006) (3.4-4.1 ng. $\left.{ }^{-1}\right)$. Since CSO concentrations are higher than concentrations found in bulk deposition for Paris (0.6 and $8.1 \mathrm{ng} .1^{-1}$ for $\Sigma 7$ PCBs, according to Blanchard et al., 2007), the difference in PCB concentrations during dry and wet periods can most certainly be explained by the remobilisation of PCB stock either on the urban surfaces or within the combined sewer. The difference in PCB distributions between bulk deposition and CSO, as characterised by a more pronounced contribution of heavy congeners (PCB 138, 153 and 
1 180), has confirmed these local inputs. Surprisingly, CSO concentrations are far less than the values reported for stormwater by Zgheib et al. (2011b, same issue), i.e. 74, 272 and $711 \mathrm{ng} .1^{-}$

${ }^{1}$ for d10, d50 and d90, respectively, based on $\Sigma 7$ PCBs. These differences may be due to either a higher probability of finding PCB stock in suburban catchments or the higher remobilisation of PCB stock on these catchments. Further investigation is now required to better understand these differences.

\section{Tributyltin compounds}

The concentrations of tributyltin* (TBT*), dibutyltin* (DBT*) and monobutyl* (MBT*) compounds are all illustrated in Figure 4. Whereas $\mathrm{C} 1, \mathrm{C} 2$ and $\mathrm{C} 4$ discharges exhibit similar concentration ranges $\left(29-32\right.$ ng. $1^{-1}$ for TBT*, 30-47 ng. T $^{-1}$ for DBT* and 47-64 ng. . $^{-1}$ for $\mathrm{MBT}^{*}$ ), discharge $\mathrm{C} 3$, which features a higher wastewater proportion, revealed 2-10 times higher concentrations $\left(105,220\right.$ and 750 ng.1 ${ }^{-1}$ for $\mathrm{TBT}^{*}, \mathrm{DBT}^{*}$ and $\mathrm{MBT}^{*}$, respectively). These concentrations were explained by a higher TS concentration, along with an increase of the organotin contents in these particles. As an example, for $\mathrm{MBT}^{*}$, a distinct content difference was observed $\left(0.75 \mu \mathrm{g} \cdot \mathrm{g}^{-1} . \mathrm{dw}\right.$ vs. $\left.0.18-0.35 \mu \mathrm{g} \cdot \mathrm{g}^{-1} . \mathrm{dw}\right)$. In CSOs, the distributions were clearly marked by the predominance of MBT* (38\%-68\%), followed by DBT* $(19 \%$ $38 \%$ ). Up until this point however, the occurrences of $\mathrm{MBT}^{*}$ and $\mathrm{DBT}^{*}$ have primarily been correlated with the microbial and/or photochemical degradation of $\mathrm{TBT}^{*}$, as the presence of both compounds and their lack of dependence on $\mathrm{TBT}^{*}$ provide support to the notion that $\mathrm{DBT}^{*}$ and $\mathrm{MBT}^{*}$ occur not only as degradation products of $\mathrm{TBT}^{*}$.

Except for discharge C3, which clearly exhibits higher concentrations than those reported in either stormwater (Zgheib et al., 2011, same issue) or wastewater, no notable difference in concentration ranges appears for $\mathrm{TBT}^{*}, \mathrm{DBT}^{*}$ and $\mathrm{MBT}^{*}$ in $\mathrm{CSO}$, wastewater and stormwater (Figs. 1 and 2). These similar concentration ranges observed across all matrices are certainly derived from the frequency of organotin occurrence and its wide 
1 industrial applications (pesticides used in agriculture, wood preservatives, industrial water

2 cooling towers, and many types of PVC applications). Recent evidence has been found of the direct input of $\mathrm{MBT}^{*}$ and $\mathrm{DBT}^{*}$, most likely caused by leaching from PVC materials and house paint (Hoch, 2001). Even if the concentration ranges were quite similar for all matrices, the wastewater was characterised by a higher $\mathrm{TBT}^{*}$ proportion, whereas stormwater and CSO distributions were more readily dominated by $\mathrm{MBT}^{*}$ and $\mathrm{DBT}^{*}$. This finding could confirm that the leaching of building materials (PCV, house paint, etc.) releases both compounds.

\section{Volatile organic compounds (VOCs)}

Out of the 12 VOCs monitored, only tetrachloroethylene was detectable in all samples (2.6-9.0 $\left.\mu \mathrm{g} . \mathrm{l}^{-1}\right)$, while ethylbenzene, toluene, xylene and trichloroethylene were occasionally detected (occurrence frequency varied from $25 \%$ to $50 \%$ ). For the discharge $\mathrm{C} 3$ (i.e. with the highest wastewater proportion), 5 VOCs were detected vs. 1 or 2 compounds for the other discharges, thus suggesting that wastewater constitutes the major source of VOCs. The results published by Zgheib et al. (2011b, same issue), which indicate that VOCs are never quantified in stormwater except for methylene chloride (1.5-13 $\left.\mu \mathrm{g} . \mathrm{l}^{-1}\right)$ and tetrachloroethylene (0.5-1.3 $\left.\mu \mathrm{g} . \mathrm{l}^{-1}\right)$, along with the levels reported in the literature for wastewater (Wilkie et al., 1996; Rule et al., 2006a) have confirmed this hypothesis. A higher number of VOCs were indeed detected in wastewater (at least 10 compounds, Fig. 1). In wastewater, methylene chloride (4.8-6.4 $\left.\mu \mathrm{g} . \mathrm{l}^{-1}\right)$ and tetrachloroethylene (1.6-6.7 $\left.\mu \mathrm{g} . \mathrm{l}^{-1}\right)$ were predominant, while other compounds lie in the 0.1-2.3 $\mu \mathrm{g} .1^{-1}$ range. According to US-EPA, methylene chloride is used in various industrial processes, spanning many different industries including paint stripping, pharmaceutical manufacturing, paint remover manufacturing and metal cleaning and degreasing. Similarly, owing to its excellent degreasing properties, tetrachloroethylene is a widely preferred degreasing agent and solvent, therefore explaining its presence in numerous household products (automobile cleaners, paint removers and strippers, etc.). 


\section{Pesticides}

Out of the 25 pesticides monitored, 9 corresponding for the most part to herbicides were detected in CSOs (Fig. 1). Aldrin, atrazine* and desethylatrazine were also occasionally detected (occurrence rates of between $25 \%$ and 50\%), while dieldrin $\left(0.20-0.98 \mu \mathrm{g} .1^{-1}\right)$, diuron* $\left(0.19-0.50 \mu \mathrm{g} . .^{-1}\right)$, isoproturon* $\left(0.02-0.04 \mu \mathrm{g} .1^{-1}\right)$, aminotriazole $\left(0.13-0.46 \mu \mathrm{g} . .^{-1}\right)$, glyphosate (0.29-1.2 $\left.\mu \mathrm{g} . \mathrm{l}^{-1}\right)$ and amino methyl phosphonic acid - AMPA (0.25-1.6 $\left.\mu \mathrm{g} .1^{-1}\right)$ were detected in all samples. On the whole, these pesticides were ubiquitous and found in CSOs, wastewater and stormwater. As demonstrated in Figures 1 and 2 however, pesticide patterns and levels differed depending on the matrix under consideration. The CSO discharges featured concentrations of diuron*, isoproturon* and glyphosate 5 to 20 times higher than those observed in wastewater, yet remaining in a range similar to what was reported by Zgheib et al. (2011b, same issue) for stormwater. It can therefore be assumed that these pollutants mainly originate from stormwater and are due to the leaching of these herbicides on impervious urban surfaces. As underscored by Blanchoud et al. (2004) for diuron*, these herbicides are indeed capable of being remobilised during a rainfall event. For AMPA, the CSO concentrations were found in the lower range of what was observed for wastewater, far less than those reported for stormwater. This finding indicates that wastewater can be a major contributor of AMPA in CSOs. According to Skark et al. (1998), the presence of AMPA in wastewater is more likely to be correlated with the degradation of phosphonic acids in detergents than with the primary degradation of glyphosate (Skark et al., 1998).

\section{Polyethoxylate alkylphenols (APEOs)}

For polyethoxylate alkylphenols (APnEOs), nonylphenols* (NP*, 0.6-2.2 $\mu \mathrm{g} .1^{-1}$ ) and 4-tert-octylphenol* (OP*, 0.1-0.2 $\mu \mathrm{g} . \mathrm{l}^{-1}$ ) were initially monitored in CSOs. NP* was predominant, as compared to $\mathrm{OP}\left(10<\mathrm{NP} * / \mathrm{OP}^{*}<35\right.$, which is in good agreement with their use and production specifications (Ying et al., 2002), and mainly associated with particles 
1 (from 58\% to 86\%). Given that APnEOs containing between 6 and 12 ethoxylate units

2 (NPnEO and OPnEO) are the most significant from a commercial standpoint, a monitoring campaign devoted solely to both the endocrine-disrupting chemicals $\mathrm{NP}^{*}$ and $\mathrm{OP}^{*}$ is not sufficiently accurate and provides just very limited information. Complementary analyses were therefore also carried out in order to analyse NP1EO, NP2EO, OP1EO and OP2EO, as well as nonylphenol ethoxyacetic acid (NP1EC), a known degradation product of long-chain NPnEOs (Fig. 3). The concentrations found in CSOs ranged from 448 to $1,526 \mathrm{ng} . \mathrm{l}^{-1}$ for NP1EO, from 171 to $401 \mathrm{ng} . \mathrm{l}^{-1}$ for NP2EO, and from 221 to $591 \mathrm{ng} . \mathrm{l}^{-1}$ for NP1EC.

As for PAHs or some of the pesticides, $\mathrm{NP}^{*}$ and $\mathrm{OP}^{*}$ were quantified in $\mathrm{CSO}$, wastewater and stormwater, thus confirming their dissemination into the urban environment. From an overall perspective, CSOs presented similar or higher NP* and OP* concentrations than those found in wastewater, though exceeding by far the values reported for stormwater (Zgheib et al., 2011, same issue), suggesting the contribution of in-sewer deposit erosion. This trend was confirmed by Gilbert et al. (2010) for long-chain APnEOs within the Paris sewer network. Although the presence of APEOs in wastewater is now well documented and related to their widespread use as surfactants in numerous industrial and commercial applications or in plastics (Ying et al., 2002), the presence of APEOs in stormwater must be pointed out and these concentrations must be taken into consideration. Current knowledge on APnEO emissions in runoff is however rather limited. Based on the values reported by Zgheib et al. (2011b, same issue), Bressy et al. (2011) and Björklund et al. (2009) confirmed that high levels of APEOs could be found in runoff. For instance, Björklund et al. (2009) reported $\mathrm{NP} *$ concentrations ranging from 100 (suburban residential catchment) to 1,200 ng.1 ${ }^{-1}$ (a highdensity traffic catchment). According to both studies, the high levels of APEOs in runoff can be explained by local contributions from building and road runoff, since APEOs are used in civil engineering materials, paints and the production of sealants. The initial investigations on 
1 stormwater identified levels close to $70-100 \mathrm{ng} . \mathrm{l}^{-1}$ for NP1EO and roughly 100-140 $\mathrm{ng} . \mathrm{l}^{-1}$ for

2 NP2EO, yet confirmation will require further experimentation. It is surprising that NP1EC, generally considered as an aerobic degradation product of $\mathrm{NPnEO}$, were also quantified in stormwater at levels of around $300 \mathrm{ng} . \mathrm{l}^{-1}$; its origins need to be studied in greater detail.

\section{Diethylhexyl phthalate (DEHP*)}

Concentrations of diethylhexyl phthalate* (DEHP*) in CSOs ranged between 3.8 and $14.8 \mu \mathrm{g} .1^{-1}$; these values tended towards the lower range of what was reported by Gasperi et al. (2008) for CSOs in the Paris sewer network (16-57 $\mu \mathrm{g} \cdot \mathrm{l}^{-1}$, with a median of $\left.22 \mu \mathrm{g} \cdot \mathrm{l}^{-1}\right)$. No clear relationship appeared between DEHP* concentrations and the proportion of either runoff or wastewater. On the whole and given the high variability of DEHP* concentrations, the levels found in CSOs were comparable to those measured in both wastewater $(\mathrm{n}=11,13.1$ $57.3 \mu \mathrm{g} .1^{-1}$ with a median of $\left.19.1 \mu \mathrm{g} . \mathrm{l}^{-1}\right)$ and stormwater $\left(\mathrm{n}=14,3.4-55.9 \mu \mathrm{g} . \mathrm{l}^{-1}\right.$, median: 16.4 $\left.\mu \mathrm{g} . \mathrm{l}^{-1}\right)$, thus confirming the large spread of DEHP* in the urban environment. Many studies have actually identified DEHP* as the most frequently detected phthalate found at the highest concentrations in urban environments. As for the other chemicals, phthalates and more specifically DEHP* are widely used throughout industry and in households, particularly as additives in plastics and PVC products pipes. According to Björklund et al. (2009), phthalates in runoff are likely to originate from vehicle components and reclaimed asphalt conveyed during traffic flow.

\section{Chloroalkanes*}

Chloroalkanes*, which are also called short-chain chlorinated paraffins (SCCP*), have been observed in CSOs (at an occurrence rate of $75 \%$ ), with concentrations ranging from 15 to $50 \mu \mathrm{g} .1^{-1}$. Using the same analytical methodology (with a quantification limit set at $10 \mu \mathrm{g} . \mathrm{l}^{-}$ ${ }^{1}$ ), chloroalkanes* were not observed in wastewater or stormwater (Zgheib et al., 2011, same issue). Even if SCCP* are expected to be present in wastewater and CSOs since these 
1 compounds are used as lubricants and additives, as well as flame retardants in a wide range of applications, no definitive conclusion can be clearly drawn for SCCP* and moreover results must be considered carefully. As highlighted by Eljarrat and Barcelo (2006), it should be recalled that $\mathrm{SSCP}^{*}$ represent a difficult analytical problem caused by their instrumental determination and quantification, which is related to the complexity of these mixtures.

\subsection{CSO concentrations vs. Environmental Quality Standards}

In order to identify substances capable of representing a major risk to the environment, CSO concentrations were compared to the Environmental Quality Standards (EQS) established by the European Commission (Table 5). The relevant Directive defines two types of standards: i) the annual average concentration (EQS-AAC) of the substance over a 1-year period, and ii) the maximum allowable concentration (EQS-MAC) of the substance measured at specific points in time. As previously described by Zgheib et al. (2011), this approach was simple and easy, yielding an indicative rate of dilution required in the receiving environment for compliance with the WFD. Of the substances quantified in CSOs for which an EQS has been proposed, a limited number may pose environmental risks as regards compliance with standards established at the European level. No risk of exceeding EQS-AAC and EQS-MAC was observed for tri- and tetra-chloroethylenes, atrazine*, isoproturon*, octylphenol*, anthracene* and naphthalene* $(\mathrm{F}<1)$, while only a limited risk was observed for diuron*, DEHP*, nonylphenols*, benzo(a)pyrene* and fluoranthene* $(1<\mathrm{F}<10)$. On the other hand, major dilution factors were required for PAHs (sum of $\mathrm{B}(\mathrm{b}) \mathrm{F}^{*}+\mathrm{B}(\mathrm{k}) \mathrm{F}^{*}$ and sum of $\mathrm{IP}^{*}+$ $\mathrm{B}(\mathrm{ghi}) \mathrm{P}^{*}$, only for EQS-AAC) and, to a greater extent, for tributyltin compounds* (TBT*, $\mathrm{DBT}^{*}$ and $\left.\mathrm{MBT}^{*}\right)$ and chloroalkanes* in terms of both EQS-AAC and EQS-MAC. As for EQS-MAC, tributyltin* should be carefully considered, since a significant dilution factor was required (from 19 to 300). For chloroalkanes*, dilution factors were lower yet remained between 10 and 35 . 


\section{4. Conclusion}

This study, as part of the OPUR research programme, has been aimed at investigating the quality of combined sewer overflow in urban watersheds. By monitoring priority pollutants as well as additional substances, this study constitutes the first relevant approach to providing accurate knowledge on the occurrence and concentrations of a broad spectrum of pollutants in CSOs and their significance compared to wastewater and stormwater.

This work has served, first and foremost, to confirm that a wide range of PPs are indeed present in CSOs. Of the 88 stormwater priority substances monitored in both the particulate and dissolved phases, 49 different PPs, including 19 priority hazardous substances*, could be detected. Most of these were also frequently observed in wastewater and stormwater, thus confirming that PPs are now ubiquitous in our urban environment. Nevertheless, some differences relative to concentration ranges and/or pollutant patterns from one matrix to the next can still be drawn. For most hydrophobic organic pollutants, such as PAHs and APnEOs, and some preferentially particulate-bound metals ( $\mathrm{Pb}^{*}$ and $\mathrm{Cu}$ ), $\mathrm{CSOs}$ exhibit higher concentrations than those found in stormwater and wastewater. As previously demonstrated, this result is highly correlated with the significant in-sewer deposit erosion. For less hydrophobic pollutants, such as pesticides or preferentially dissolved metals like Zn, CSOs yield concentrations close to stormwater, thus suggesting that runoff is the major contributor while wastewater and in-sewer processes remain minor sources. For VOCs, wastewater seems to be the major contributor in CSOs since these compounds were not detected in stormwater. Similar concentration ranges were found for DEHP and tributyltin compounds* in CSOs, wastewater and stormwater as a result of their high inter-event variability. Lastly, a comparison of CSO concentrations with European standards underscores that $\mathrm{CSO}$ discharges may pose a significant environmental risk as regards PAHs, tributyltin 
1 compounds* and chloroalkanes*, since high dilution factors were required to comply with

EQS-AAC or EQS-MAC. Further investigation is now required to better evaluate this risk.

By providing significant knowledge on the quality of $\mathrm{CSO}$, wastewater and stormwater, this study and, more generally, the data provided by the OPUR research programme might be used in the future to identify PPs of potential significance. In the near future, such data could also serve to establish accurate mass balances in order to apportion the contributions of wastewater, runoff and in-sewer deposit erosion to CSO loads in combined sewers. This information will soon be of prime importance in reducing priority pollutant discharges within the urban environment and as part of the effort to prioritise "control at the source" interventions. Among the various issues on the horizon, one OPUR research programme priority will consist of investigating the occurrence and significance of priority pollutants in atmospheric inputs, so as to better understand the role of atmospheric fallout in urban environmental contamination.

\section{Acknowledgments}

The authors gratefully acknowledge the Seine-Normandy Water Agency (AESN), the Paris public sanitation service (SIAAP), the City of Paris, the Water and Sewage Disposal Agencies of both the Seine Saint-Denis (DEA93) and Val-de-Marne (DSEA94) Departments, and the Paris Regional Council (CRIF) for their financial support within the framework of the OPUR research programme.

\section{References}

Bjorklund, K., Cousins, A.P., Stromvall, A.M., Malmqvist, P.A. (2009). Phthalates and nonylphenols in urban runoff: Occurrence, distribution and area emission factors. Science of the Total Environment, 407(16): 4665-4672. 
Blanchard, M., Teil, M.-J., Guigon, E., Larcher-Tiphagne, K., Ollivon, D., Garban, B. and Chevreuil, M. (2007). Persistent toxic substance inputs to the river Seine basin (France) via atmospheric deposition and urban sludge application. Science of the Total Environment, Human activity and material fluxes in a regional river basin: the Seine River watershed Seine Special Issue 375(1-3), 232-243.

Blanchoud, H., Farrugia, F. and Mouchel, J.M. (2004) Pesticide uses and transfers in urbanised catchments. Chemosphere 55(6), 905-913.

Bressy, A., Gromaire, M.C., Lorgeoux, C., Chebbo, G. (2011). Alkylphenols in atmospheric depositions and urban runoff. Water Science and Technology, 63(4): 671-679.

Chebbo G. and Saget A. (1995). Pollution of urban wet weather discharges. In: Encyclopedia of environmental biology, Academic press, 171-182.

Chevreuil, M., Blanchard, M., Teil, M.J., Carru, A.M., Testard, P. and Chesterikoff, A. (1996). Evaluation of the pollution by organochlorinated compounds (polychlorobiphenyls and pesticides) and metals $\mathrm{Cd}, \mathrm{Cr}, \mathrm{Cu}$ and $\mathrm{Pb}$ in the water and in the zebra mussel (Dreissena polymorpha Pallas) of the river Seine. Water Air and Soil Pollution 88(3-4), 371-381.

Clark, S.E., Burian, S., Pitt, R., Field, R. (2006). Urban wet-weather flows. Water Environment Research 78(10), 1133-1192.

Comber, S.D.W. and Gunn, A.M. (1996). Heavy metals entering sewage-treatment works from domestic sources. Journal of the Chartered Institution of Water and Environmental Management 10(2), 137-142.

Davis, A.P., Shokouhian, M. and Ni, S. (2001). Loading estimates of lead, copper, cadmium, and zinc in urban runoff from specific sources. Chemosphere 44(5), 997-1009.

Deletic, A. (1998). The first flush load of urban surface runoff. Water Research 32(8), 2462-2470. 

W. (2010). Stormwater quality models: performance and sensitivity analysis. Water Science and Technology 62(4), 837-843.

Eljarrat, E. and Barcelo, D. (2006). Quantitative analysis of polychlorinated n-alkanes in environmental samples. Trac-Trends in Analytical Chemistry 25(4), 421-434.

Eriksson, E., Baun, A., Scholes, L., Ledin, A., Ahlman, S., Revitt, M., Noutsopoulos, C. and Mikkelsen, P.S. (2007) Selected stormwater priority pollutants - a European perspective. Science of the Total Environment 383(1-3), 41-51.

Eriksson, E., Donner, E. and Ledin, A. (2010). Presence of selected priority and personal care substances in an onsite bathroom greywater treatment facility. Water Science and Technology 62(12), 2889-2898.

Gasperi, J., Gromaire, M.C., Kafi, M., Moilleron, R. and Chebbo, G. (2010). Contributions of wastewater, runoff and sewer deposit erosion to wet weather pollutant loads in combined sewer systems. Water Research 44(20), 5875-5886.

Gasperi, J., Kafi-Benyahia, M., Lorgeoux, C., Moilleron, R., Gromaire, M.C., Chebbo, G. (2008). Wastewater quality and pollutant loads in combined sewers during dry weather periods. Urban Water Journal 5, 305-314.

Gasperi, J., Garnaud, S., Rocher, V. and Moilleron, R. (2009). Priority pollutants in surface waters and settleable particles within a densely urbanised area: Case study of Paris (France). Science of the Total Environment 407(8), 2900-2908.

Gilbert, S., Gasperi, J., Rocher, V., C, Lorgeoux and Chebbo, G. (2010). Removal of PBDE and alkylphenol in a trickling filter wastewater treatment plant during dry and wet weather periods. Proceeding of the 11th European Meeting on Environmental Chemistry, Portoroz (Slovenia). 
Gromaire, M.C., Chebbo, G., Constant, A. (2002). Impact of zinc roofing on urban runoff pollutant loads: the case of Paris. Water Science and Technology 45(7), 113-122.

Gromaire, M.C., Garnaud, S., Saad, M., Chebbo, G. (2001). Contribution of different sources to the pollution of wet weather flows in combined sewers. Water Research $35(2)$, $521-533$.

Hoch, M. (2001). Organotin compounds in the environment - an overview. Applied Geochemistry 16(7-8), 719-743.

Iannuzzi, T.J., Huntley, S.L., Schmidt, C.W., Finley, B.L., McNutt, R.P. and Burton, S.J. (1997). Combined sewer overflows (CSOs) as sources of sediment contamination in the lower Passaic River, New Jersey .1. Priority pollutants and inorganic chemicals. Chemosphere 34(2), 213-231.

Kafi, M., Gasperi, J., Moilleron, R., Gromaire, M.C., Chebbo, G. (2008). Spatial variability of the characteristics of combined wet weather pollutant loads in Paris. Water Research 42(3), 539-549.

Lau, S.L., Han, Y., Kang, J.H., Kayhanian, M. and Stenstrom, M.K. (2009). Characteristics of Highway Stormwater Runoff in Los Angeles: Metals and Polycyclic Aromatic Hydrocarbons. Water Environment Research 81(3), 308-318.

Rossi, L., de Alencastro, L., Kupper, T. and Tarradellas, J. (2004). Urban stormwater contamination by polychlorinated biphenyls (PCBs) and its importance for urban water systems in Switzerland. Science of the Total Environment 322(1-3), 179-189.

Rowsell, V.F., Tangney, P., Hunt, C. and Voulvoulis, N. (2010). Estimating Levels of Micropollutants in Municipal Wastewater. Water Air and Soil Pollution 206(1-4), 357-368.

Ruel, S.M., Esperanza, M., Choubert, J.M., Valor, I., Budzinski, H. and Coquery, M. (2010). On-site evaluation of the efficiency of conventional and advanced secondary 
1 processes for the removal of 60 organic micropollutants. Water Science and Technology 62(12), 2970-2978.

Rule, K.L., Comber, S.D.W., Ross, D., Thornton, A., Makropoulos, C.K., Rautiu, R. (2006a). Sources of priority substances entering an urban wastewater catchment--trace organic chemicals. Chemosphere 63, 581-591.

Rule, K.L., Comber, S.D.W., Ross, D., Thornton, A., Markropoulos, C.K., Rautiu, R. (2006b). Survey of priority substances entering thirty English wastewater treatment works. Water and Environment Journal 20, 177-184.

Skark, C., Zullei-Seibert, N., Schottler, U., Schlett, C. (1998). The occurrence of glyphosate in surface water. International Journal of Environmental Analytical Chemistry 70, 93-104.

Soclo, H.H., Garrigues, P. and Ewald, M. (2000). Origin of polycyclic aromatic hydrocarbons (PAHs) in coastal marine sediments: case studies in Cotonou (benin) and Aquitaine (France) areas. Marine Pollution Bulletin 40(5), 387-396.

Suarez, J. and Puertas, J. (2005). Determination of COD, BOD, and suspended solids loads during combined sewer overflow (CSO) events in some combined catchments in Spain. Ecological Engineering 24(3), 201-219.

Tchobanoglous, G., Burton, F., Stensel, H. (2003). Wastewater Engineering. Treatment and Reuse. 4th ed. Metcalf and Eddy, McGraw-Hill, New York, 1819 p.

Vogelsang, C., Grung, M., Jantsch, T.G., Tollefsen, K.E., Liltved, H. (2006). Occurrence and removal of selected organic micropollutants at mechanical, chemical and advanced wastewater treatment plants in Norway. Water Research 40, 3559-3570.

Wilkie, P.J., Hatzimihalis, G., Koutoufides, P. and Connor, M.A. (1996). The contribution of domestic sources to levels of key organic and inorganic pollutants in sewage: The case of Melbourne, Australia. Water Science and Technology 34(3-4), 63-70. 

and alkylphenol ethoxylates--a review. Environment International 28, 215-226. between dissolved and particulate phases: What about emerging substances in urban stormwater catchments? Water Research 45(2), 913-925.

Zgheib, S., Moilleron, R. and Chebbo, G. (2011). Priority pollutants in urban stromwater: part 1 - case of separate storm sewers. Water Research, special issue on stormwater.

Zgheib S., Moilleron R. and Chebbo G., (2010). What priority pollutants occurred in stormwater and wastewater? Water Pollution X, Editors A. M. Marinov, C.A. Brebbia, Book Series: WIT Transactions on Ecology and the Environment, 135, 3-13. Zgheib, S., Moilleron, R., Chebbo, G. (2008). Screening of priority pollutants in urban stormwater: innovative methodology. Water Pollution IX 111, 235-244. 


\section{Figure captions}

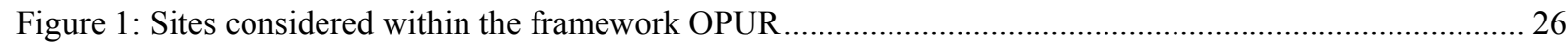

Figure 2: Total concentration (in $\mu \mathrm{g} / \mathrm{l})$ for CSOs $(\mathrm{n}=4)$, wastewater $(\mathrm{n}=11)$ and stormwater in a separated sewer $(\mathrm{n}=17)$, as well as occurrence rates (\%). For wastewater and stormwater, d10, d50 and d90 concentrations are illustrated as well................................................................................................................... 27

Figure 3: Ratios between CSO and median wastewater concentrations (white circles) and between CSO and

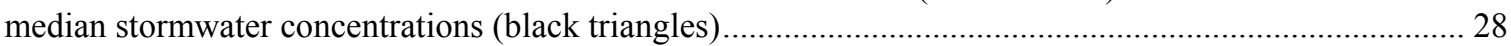

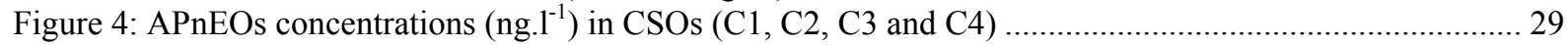




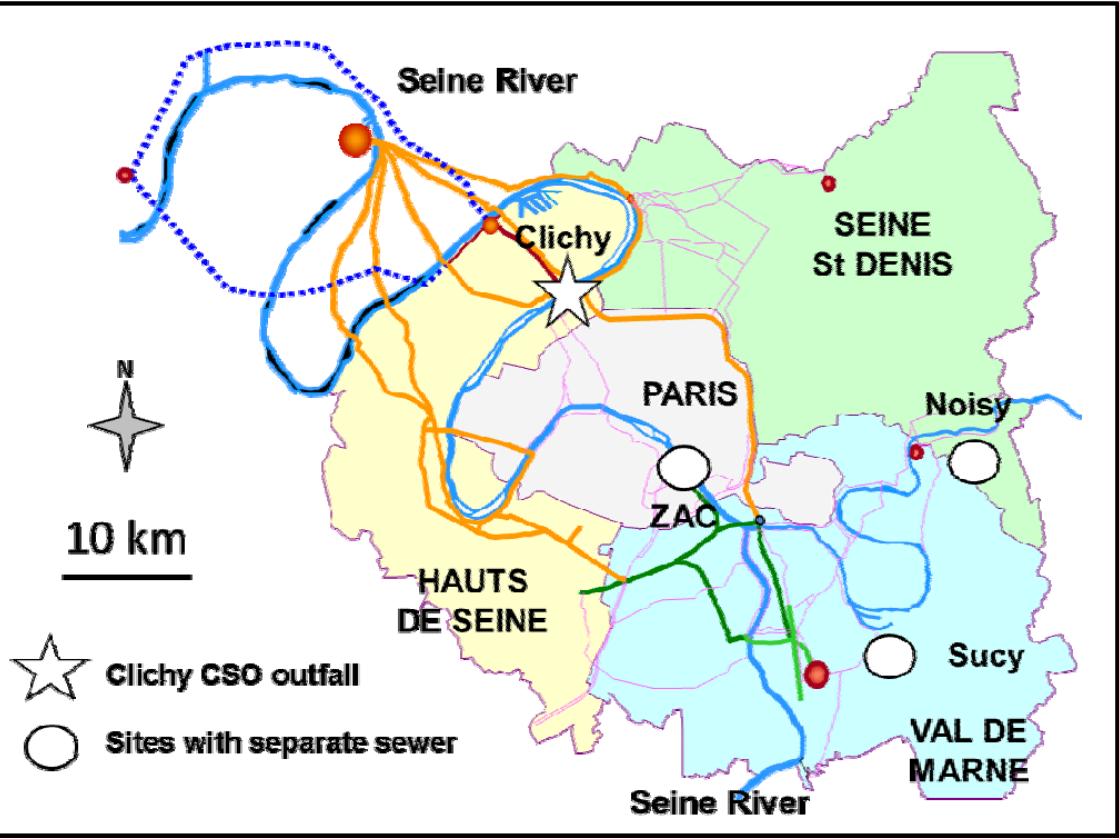

Figure 1: Sites considered within OPUR research program. The Clichy outfall was considered for CSO, while Noisy, Sucy and ZAC sites were dedicated to study the stormwater quality in connection with the urbanisation gradient (Zgheib et al., 2011a) 

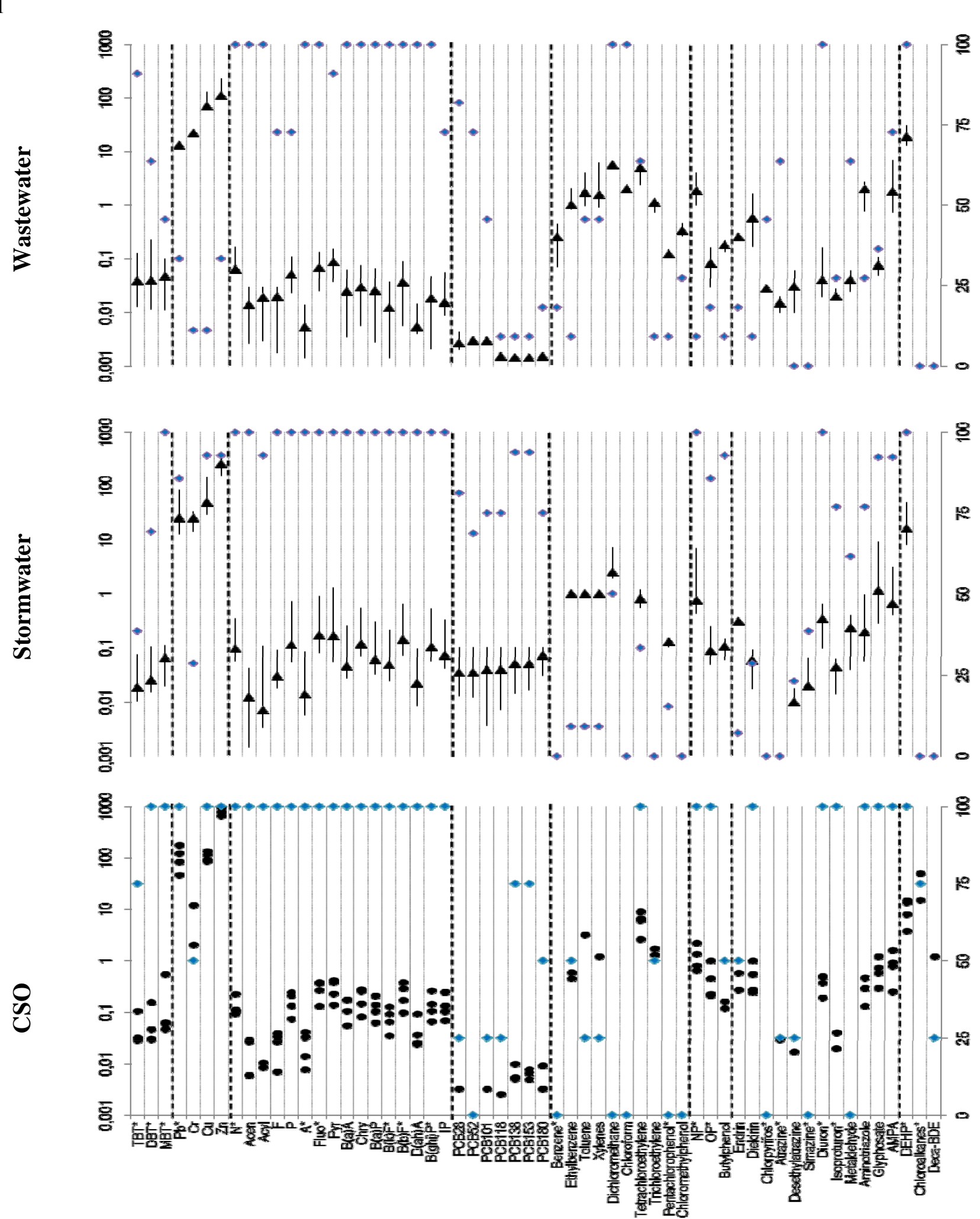

Figure 2: Total concentration ( $\mu \mathrm{g} . \mathrm{L}^{-1}$, left axis) for CSOs $(\mathrm{n}=4)$, wastewater $(\mathrm{n}=11)$ and stormwater in a separated sewer $(\mathrm{n}=17)$, as well as occurrence rates (blue lozenges, in \%, right axis). CSO samples were collected in 2010, wastewater in 2009-2010, and stormwater over the 2008-2010 period. For stormwater and wastewater, lines illustrate the first and last decile concentrations (d10 and d90), and black triangles refer to median (d50). 


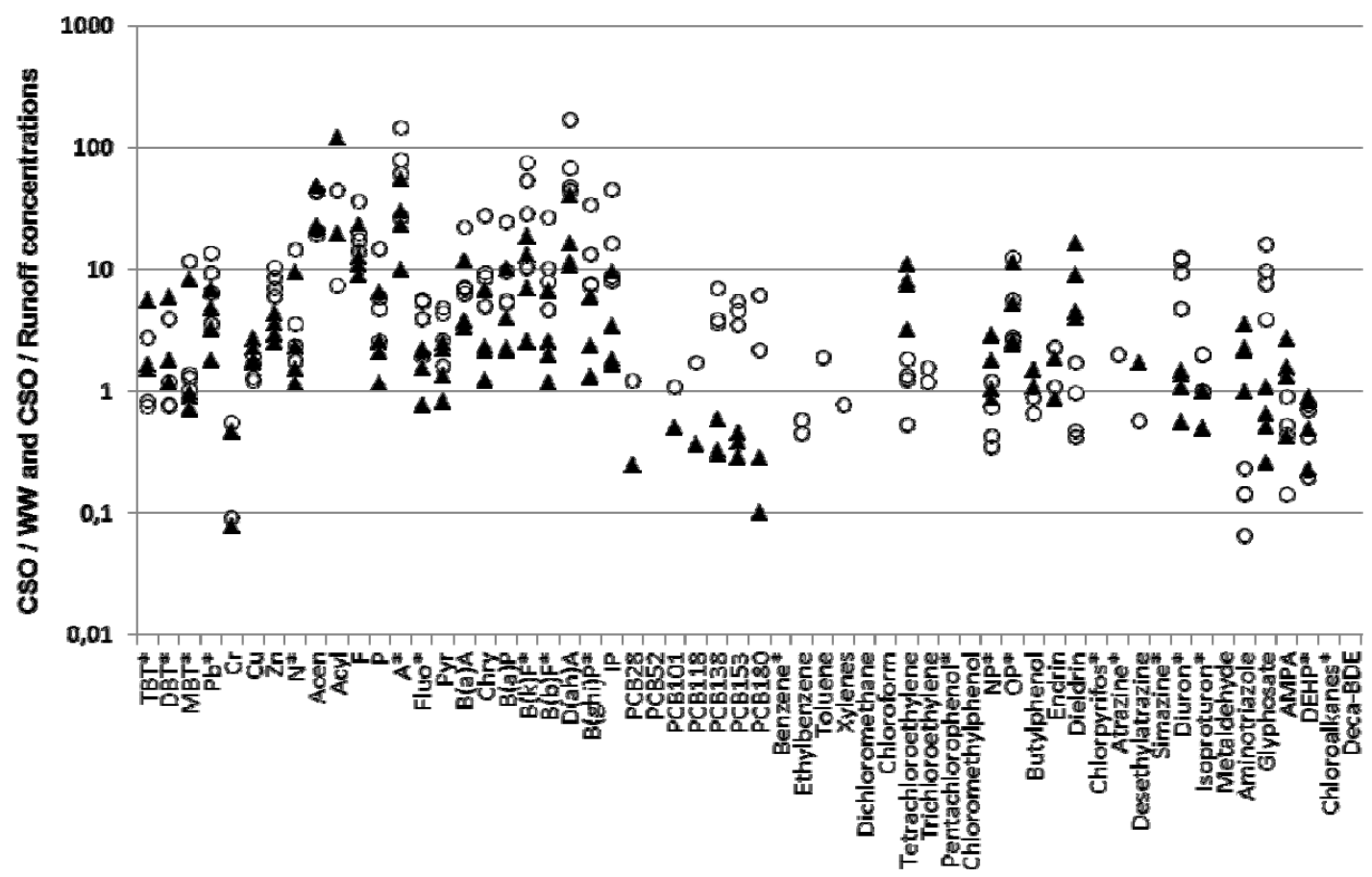

Figure 3: Ratios between CSO and median wastewater concentrations (white circles) and between $\mathrm{CSO}$ and median stormwater concentrations (black triangles) 

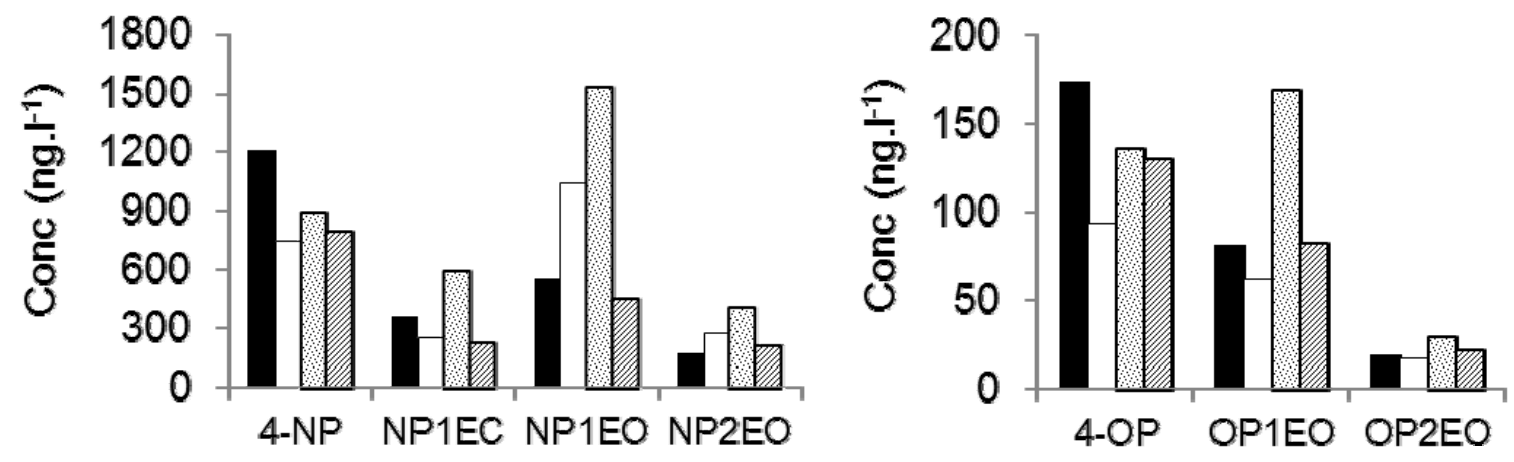

Figure 4: APnEOs concentrations (ng. $\left.1^{-1}\right)$ in CSOs (C1, C2, C3 and C4) 


\section{Table captions}

3 Table 1: Main characteristics of the rain events studied and runoff proportions using $4 \quad$ conductivity or nitrogenous measurements ................................................................... 31

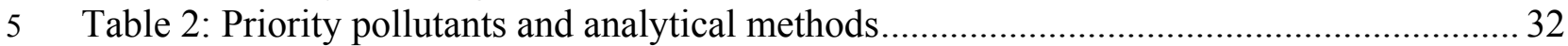

6 Table 3: Wastewater quality parameters for the rain events studied .......................................33

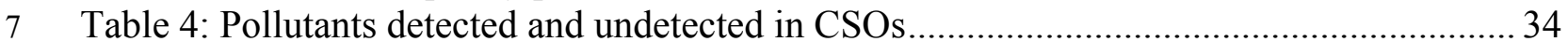


Table 1: Main characteristics of the rain events studied and runoff proportions

\begin{tabular}{ccccccc}
\hline Date & & $\begin{array}{c}\mathrm{H}^{1} \\
(\mathrm{~mm})\end{array}$ & $\begin{array}{c}\text { Volume } \\
\left(\mathrm{m}^{3}\right)\end{array}$ & $\begin{array}{c}\mathrm{ADP}^{2} \\
(\mathrm{~d})\end{array}$ & $\begin{array}{c}\mathrm{Cond}^{3} \\
\left(\mu{\left.\mathrm{S} . \mathrm{cm}^{-1}\right)}^{2}\right.\end{array}$ & $\begin{array}{c}\text { Runoff }(\%)^{4} \\
\text { Min-Max }\end{array}$ \\
\hline $2010 / 07 / 12$ & C1 & 32.9 & 559,390 & 9 & 284 & $78-87$ \\
$2010 / 07 / 14$ & C2 & 43.1 & $1,005,150$ & 2 & 201 & $87-95$ \\
$2010 / 09 / 08$ & C3 & 13.2 & 39,200 & 16 & 380 & $69-77$ \\
$2010 / 09 / 24$ & C4 & 16.5 & 325,175 & 16 & 260 & $75-89$
\end{tabular}

(1) $H=$ precipitation height for each rain event $(\mathrm{mm})$, (2) ADP = antecedent dry period, time period since the previous rain event (day), (3) Cond = conductivity, in $\mu S . \mathrm{cm}^{-1}$, (4) runoff proportion, estimation based on conductivity measurement. 
Table 2: List of monitored priority $\mathrm{p}$ ollutants and analytical methods

\begin{tabular}{|c|c|c|c|c|}
\hline Groups $^{1}$ & Total $^{2}$ & Standards & Methods $^{3}$ & Phase $^{4}$ \\
\hline Alkylphenols & $5(2)$ & ISO $18857-1$ & GC-MSMS & $P+D$ \\
\hline BTEX & $5(1)$ & NF EN ISO 11423-1 & GC-MS & $\mathrm{T}$ \\
\hline Chloroalkanes & $1(1)$ & Internal method & GC-ECD & $P+D$ \\
\hline Chlorobenzenes & $5(3)$ & EN ISO 6468 & GC-MS & $\mathrm{P}+\mathrm{D}$ \\
\hline Chlorophenols & $1(1)$ & NF EN 12673 + ISO 6468 & GC-MSMS & $\mathrm{P}+\mathrm{D}$ \\
\hline HVOCs & $7(4)$ & NF EN ISO $10301+6468$ & GC-MS & $\mathrm{T}$ \\
\hline PAHs & $16(8)$ & ISO 17993 & HPLC-Fluo & $P+D$ \\
\hline Metals & $8(4)$ & NF EN ISO $11885+1483$ & ICP and AAS & $\mathrm{T}+\mathrm{D}$ \\
\hline Organotins & $3(3)$ & NF EN ISO 17353 & GC-MS & $\mathrm{P}+\mathrm{D}$ \\
\hline PBDEs & $3(1)$ & ISO 22032 & GC-ECD & $\mathrm{P}+\mathrm{D}$ \\
\hline PCBs & 8 & NF EN ISO 6468 & GC-MS-MS & $\mathrm{P}+\mathrm{D}$ \\
\hline Pesticides & 25( & $\begin{array}{l}\text { NF EN ISO } 11369+\text { Internal } \\
\text { method }\end{array}$ & $\begin{array}{l}\text { GC-MS } \\
\text { UPLC-MSMS }\end{array}$ & $\mathrm{P}+\mathrm{D}$ \\
\hline Phthalates & $1(1)$ & Internal method & GC-MS & $\mathrm{P}+\mathrm{D}$ \\
\hline
\end{tabular}

(1) Compound groups: $B T E X=$ benzene*, toluene, ethylbenzene and xylenes, $H V O C=$ halogenated volatile organic compounds, $P A H s=$ polycyclic aromatic hydrocarbons, $P B D E=$ polybromodiphenylethers, $P C B=$ polychlorinated biphenyls, (2) The substance in brackets is listed in the WFD, (3) Analytical methods: ICP = inductively coupled plasma, AAS = atomic absorption spectrometry, GC = gas chromatography, GC-ECD = GC with electron capture detector, GC-MS = GC with mass spectrometer, GC-MSMS = GC gas chromatography with tandem mass spectrometer, HPLC-fluo = High pressure liquid chromatography with fluorescent detector, UPLC-MSMS = ultra performance liquid chromatography with tandem mass spectrometer, (4) Phase considered with: $D=$ dissolved, $P=$ particulate, $T=$ Total. 
Table 3: Wastewater quality parameters for the studied CSO discharges

\begin{tabular}{|c|c|c|c|c|c|c|c|}
\hline & $\mathrm{C} 1$ & $\mathrm{C} 2$ & $\mathrm{C} 3$ & $\mathrm{C} 4$ & $\begin{array}{c}\text { CSO } \\
\text { database }\end{array}$ & $\begin{array}{c}\text { WW } \\
\text { database }^{2}\end{array}$ & Runoff $^{3}$ \\
\hline $\begin{array}{c}\text { TS } \\
\text { mg. } .^{-1}\end{array}$ & 193 & 135 & 353 & 153 & $\begin{array}{c}121-394 \\
237\end{array}$ & $\begin{array}{c}190-314 \\
252\end{array}$ & $\begin{array}{c}30-75 \\
36\end{array}$ \\
\hline $\begin{array}{c}\mathrm{COD} \\
\mathrm{mg} \mathrm{O}_{2} \cdot \mathrm{l}^{-1}\end{array}$ & 254 & 136 & 446 & 260 & $\begin{array}{c}157-491 \\
336\end{array}$ & $\begin{array}{c}322-520 \\
436\end{array}$ & $\begin{array}{c}43-113 \\
56\end{array}$ \\
\hline $\begin{array}{c}\mathrm{BOD}_{5} \\
\mathrm{mg} \mathrm{O}_{2} \cdot 1^{-1}\end{array}$ & 78 & 36 & 180 & 95 & $\begin{array}{c}54-200 \\
135\end{array}$ & $\begin{array}{c}130-230 \\
180\end{array}$ & $\begin{array}{c}8-25 \\
11\end{array}$ \\
\hline $\begin{array}{c}\text { TKN } \\
\text { mg N. } .^{-1}\end{array}$ & 17 & 7.2 & 27 & 18 & $\begin{array}{c}15-37 \\
22\end{array}$ & $\begin{array}{c}31-49 \\
41\end{array}$ & $<4$ \\
\hline $\begin{array}{c}\mathrm{NH}_{4}^{+} \\
\mathrm{mg} \mathrm{N} .1^{-1}\end{array}$ & 6.4 & 3.3 & 9.3 & 8.1 & $\begin{array}{c}5.8-22.2 \\
9.9\end{array}$ & $\begin{array}{c}20-32 \\
28\end{array}$ & - \\
\hline $\begin{array}{c}\mathrm{PO}_{4}^{3-} \\
\mathrm{mg} \mathrm{P}^{3-1^{-1}}\end{array}$ & 0.8 & 0.5 & 1.4 & 1.1 & $\begin{array}{c}0.8-2.2 \\
1.2\end{array}$ & $\begin{array}{c}2.0-3.0 \\
2.6\end{array}$ & - \\
\hline $\begin{array}{c}\text { Ptot } \\
\text { mg P. } .^{-1}\end{array}$ & 2.7 & 1.2 & 5.4 & 3 & $\begin{array}{c}2.3-5.4 \\
3.5\end{array}$ & $\begin{array}{c}4.1-6.4 \\
5.4\end{array}$ & - \\
\hline
\end{tabular}

(1) CSO database from SIAAP $(n=52)$ for the 2009-2010 period, (2) Wastewater database from SIAAP on the Clichy site ( $n=460)$, (3) runoff, data from Kafi et al. (2008). For CSO database, wastewater database, and runoff rows, first line refers to d10 and d90 concentrations; second line is median concentration (d50.) 
Never detected

in CSOs, wastewater and runoff or when detected with an occurrence $<$ $15 \%$ (30 PPs, incl. 14 PHS*)

\section{$\mathrm{Cd}^{*}, \mathrm{Hg}^{*}, \mathrm{Ni}^{*}, \mathrm{Pt}$}

dichloroethane*, trichlorobenzenes* (3), pentachlorobenzene*, hexachlorobenzene*, carbon tetrachloride, isopropylbenzene hexachlorobutadiene*, hexachlorocyclohexane*

endosulfan* (2), alachlor*, isodrin, lindane*, chlorfenvinphos*, desethylsimazine, endrin, trifluralin*, DDT (2)

PCB 194, octa-BDE, penta-BDE, 4-n-octylphenol*, 4-paranonylphenol

\begin{tabular}{|c|c|}
\hline $\begin{array}{l}\text { Undetected in CSOs, but } \\
\text { detected in wastewater } \\
\text { and runoff ( } 9 \text { PPs, incl. } \\
5 \text { PHS*) }\end{array}$ & $\begin{array}{l}\text { chloromethylphenol, benzene*, } \\
\text { chlorpyrifos*, simazine*, } \\
\text { pentachlorophenol* }\end{array}$ \\
\hline Detected in CSOs (49 & 4 metals $\left(\mathrm{Pb}^{*}, \mathrm{Cr}, \mathrm{Cu}, \mathrm{Zn}\right)$ \\
\hline PPs, incl. 19 PHS) & $\begin{array}{l}5 \text { COVs (ethylbenzene, toluene, xylenes, tetrachloroethylene, } \\
\text { trichloroethylene) } \\
9 \text { pesticides (aldrin, dieldrin, atrazine*, desethylatrazine, diuron*, } \\
\text { isoproturon*, aminotriazole, glyphosate, AMPA) } \\
3 \text { organotins (TBT*, DBT*, MBT*) } \\
3 \text { alkylphenols (nonylphenol*, octylphenol*, butylphenol) } \\
16 \text { US-PAHs (N*, Acen, Acyl, F, P, A*, Fluo*, Pyr, B(a)A, Chry, } \\
\text { B(a)P*, B(b)F*, B(k)F*, D(ah)A, B(ghi)P*, IP*) } \\
7 \text { PCBs (28, 101, 118, 138, } 153 \text { and 180) } \\
\text { Deca-BDE, chloroalkanes*. DEHP* }\end{array}$ \\
\hline
\end{tabular}


Table 5: Ratios of CSO concentrations and EQS-AAC or EQS-MAC

\begin{tabular}{|c|c|c|}
\hline & CSO concentration / EQS-AAC & CSO concentration / EQS-MAC \\
\hline Undetected & 24 PPs & $15 \mathrm{PPs}$ \\
\hline$<1$ & $\begin{array}{l}7 \text { PPs: tri- and tetra-chloroethylenes } \\
\text { atrazine*, isoproturon* } \\
\text { octylphenol* } \\
\text { anthracene*, naphthalene* }\end{array}$ & $\begin{array}{c}8 \text { PPs: tri- and tetra-chloroethylenes } \\
\text { atrazine*, isoproturon*, diuron* } \\
\text { nonylphenols* } \\
\text { anthracene*, fluoranthene* }\end{array}$ \\
\hline $1-10$ & $\begin{array}{c}5 \text { PPs: diuron*, DEHP*, } \\
\text { nonylphenols*, benzo(a)pyrene* } \\
\text { fluoranthene* }\end{array}$ & 1 PP: benzo(a)pyrene* \\
\hline $10-100$ & $\begin{array}{l}4 \text { PPs: aldrin, dieldrin, } \\
\text { chloroalkanes* } \\
\text { Sum of } \mathrm{B}(\mathrm{b}) \mathrm{F}^{*}+\mathrm{B}(\mathrm{k}) \mathrm{F}^{*}\end{array}$ & $\begin{array}{c}4 \text { PPs: } \text { TBT*}^{*}, \mathrm{DBT}^{*}, \mathrm{MBT}^{*} \\
\text { chloroalkanes* }\end{array}$ \\
\hline$>100$ & $\begin{array}{c}4 \text { PPs: } \text { TBT }^{*}, \mathrm{DBT}^{*}, \mathrm{MBT}^{*} \\
\text { Sum of IP* }+\mathrm{B} \text { (ghi) } \mathrm{P}^{*}\end{array}$ & - \\
\hline
\end{tabular}

2 